\title{
Job satisfaction and associated factors among health professionals working at Western Amhara Region, Ethiopia
}

\author{
Kalkidan Temesgen ${ }^{1}$, Moges Wubie Aycheh ${ }^{2}$ and Cheru Tesema Leshargie $2^{*^{*}}$
}

\begin{abstract}
Background: In Ethiopia assuring the satisfaction of health care provider with their job is a major challenging problem. Job satisfaction is a worker's emotional response to different job related factors resulting in finding pleasure, comfort, confidence, rewards, personal growth and various positive opportunities, including upward mobility, recognition, and appraisal done on a merit pattern with monetary value as compensation. Professionals, whose needs and expectations are satisfied, tend to be more productive compared to their colleagues. Thus, study is aimed at assessing job satisfaction and associated factors among health professionals working at Western Amhara region, Ethiopia.
\end{abstract}

Methods: An institution-based cross sectional study was conducted on March 2016 at Western Amhara region among 575 health professionals selected using simple random sampling. Logistic regression analysis was used to identify factors related to job satisfaction. Variables which have $p$-value less than or equal to 0.05 with corresponding AOR at 95 confidence interval was considered to declare the significance association.

Results: This study revealed that job satisfaction of health professional working at Western Amhara region was $31.7 \%$. The mean age of respondent was 27.13 years. Majority of them, $79.3 \%$ and $95.3 \%$ were less than 30 years in age and orthodox Christian religion followers respectively. The presence of health professionals' reference manual/ guide, alcohol drinking, workload, experience, educational status and profession types were identified as significant factors associated with health care professionals' job satisfaction level. Professional being laboratory technicians, pharmacists and Environmental health workers were 4.86 times more likely to satisfy themselves than nurses, midwives and Public health officers. Similarly, in their educational status, degree and above holders were 5.64 times more likely to satisfy themselves than below degree holders. Health professionals whose experience with $>3$ years were 2.83 times more likely to satisfy themselves than counterpart. Health professionals who had high workloads were 3.99 times more likely to satisfy than those professionals whose workload was low. Professionals who did not drink alcohol were 3.55 times more likely to satisfy themselves than professionals who drank. Professionals who consult health reference manual/guide were 15.96 more likely to satisfy themselves than those professional who did not.

Conclusion: Only one third of health professionals working at Eastern Amhara Region were satisfied on their job. The presence of health professionals' reference manual/guide, alcohol drinking, workload, experience, educational status and profession types were identified as important predictors for job satisfaction.

Keywords: Job satisfaction, Associated factors, Health professionals, Health institutions, Western Amhara, Ethiopia

\footnotetext{
* Correspondence: chertesema@gmail.com

${ }^{2}$ Department of Public Health, College of Health Science, Debre Markos

University, P.O. Box: 269, Debre Markos, Ethiopia

Full list of author information is available at the end of the article
}

(c) The Author(s). 2018 Open Access This article is distributed under the terms of the Creative Commons Attribution 4.0 International License (http://creativecommons.org/licenses/by/4.0/), which permits unrestricted use, distribution, and reproduction in any medium, provided you give appropriate credit to the original author(s) and the source, provide a link to the Creative Commons license, and indicate if changes were made. The Creative Commons Public Domain Dedication waiver (http://creativecommons.org/publicdomain/zero/1.0/) applies to the data made available in this article, unless otherwise stated. 


\section{Background}

Job satisfaction is an employee's emotional response to different job-related factors resulting in finding pleasure, comfort, confidence, rewards, personal growth and various positive opportunities, including upward mobility, recognition and appraisal done on a merit pattern with monetary value as compensation $[1,2]$. Variables that could satisfy employees differ from one to the other [3]. Any professional working in any organization has plenty of needs and expectations from the organization [4]. Professionals, whose needs and expectations are satisfied, tend to be more productive compared to their colleagues [5]. Health service delivery can be greatly affected by human resource [6]. Studies in Ethiopia showed that larger numbers of health professionals were not satisfied with their job. Low salary, limited educational development opportunity and inadequate facility and supplies were mostly described as a reason by study participants for their dissatisfactions [7].

Job satisfaction determined by a wide range of variables such as monthly salary, sufficient number of available staffs, comfortable working environment, training and growth opportunities, workload, supportive supervision provided, appreciation of good performers, timely evaluation, responsibility, relationship with the staffs and managers, job security, carrier development and other relevant behavioral and institutional factors [8].

Studies in Nepal [9], Serbia [10] and Pakistan [11] among health professionals showed that $24 \%, 77.6 \%$, and $59 \%$ were not satisfied with their job respectively. Studies done at different parts of Africa showed that job satisfaction was low that means $47.9 \%$ in South Africa [2], 29\%, in Malawi [2], $17.4 \%$ in Tanzania [2], 33.9\% in Nigeria [1]. In addition, studies conducted in Ethiopia, job satisfaction among healthcare workers was only $58.6 \%$ in Jimma [12], 34.9\% in West Showa zone [13], 53.8\% in Dessie town [14].

In Vietnam among community health workers, age, areas of work and expertise, professional education, residence, sufficient number of staff were identified as factors affecting job satisfaction [15]. Hospital politics, personal relationships and the feeling of being able to provide a good quality of care also affects job satisfaction [10]. Moreover, age group, work experience, and position were also identified as factors affecting job satisfaction among healthcare workers in Vientiane capital and Bolikhamsai province, Lao PDR [16].

According to a study conducted in Jimma University (JU), sex, age, profession, service year, position and monthly salary were identified as factors affecting job satisfaction among health care providers [12]. A similar study conducted in West Shoa Zone, Oromia Regional State, Ethiopia indicated that scheme, lack of training opportunity, and lack of incentives, bureaucratic management style, poor performance evaluation system and poor working conditions were the factors which have an association with the poor satisfaction level of health professionals [13].

Besides, all the availed information regarding health workers job satisfaction on one part of the region there is in lack of it. Therefore, this study aimed at assessing the level of job satisfaction and associated factors among health professionals working in governmental health institutions in Western Amhara Region, Ethiopia.

\section{Methods}

Study design, study area, period and population

The institution-based cross-sectional study was used to conduct this study on March, 2016 at Western Amhara region, Ethiopia. The region is broadly divided as Eastern and Western region [17]. All health professionals working in Governmental Health Institutions of western Amhara region were considered as the study populations.

\section{Sample size determination}

The sample size was determined by using a single population proportion formula considering the following assumptions: $\mathrm{n}=\left(\mathrm{Z}_{\boldsymbol{\sigma} / \mathbf{2}}\right)^{2} \mathbf{p} \quad(\mathbf{1}-\mathbf{p}) / \quad(\mathbf{d})^{2}$, Where: $\mathrm{n}=$ the required sample size, $Z_{\alpha / 2}=95 \%$ confidence interval (level of significance) (1.96), $\mathrm{P}=$ Expected proportion of the population (53.8\%) [13], $\mathrm{d}=$ Desired precision / the margin of error $(4 \%)$.

$$
n=\frac{(1.96)^{2} 0.538(1-0.538)}{(0.04)^{2}} n=597
$$

Ten percent was also added for non-response. Accordingly, the required sample size was computed and the final sample size was 657. Simple random sampling method was used to select 657 health professionals from the selected health institutions.

\section{Variable of the study Dependent Variable}

Job Satisfaction (Satisfied/Dissatisfied).

\section{Independent Variables \\ Socio-demographic characteristics}

Age, Sex, religious status, marital status, educational status and family size,

\section{Institutional characteristics}

Workload, working hour, existence of health insurance and availability of manual for reference,

\section{Behavioral characteristics}

Khat chewing, cigarette smoking and alcohol drinking. 


\section{Operational definition \\ Job satisfaction}

for this research, health professionals were considered as satisfied with their job if they answered and got the score of 9 and above questions (greater than or equal to the mean value 50\%) among 18 questions developed to assess the satisfaction level of respondents. We used the mean because the data was normally distributed.

\section{Work load}

In this research health professionals were considered as loaded if they gave service to more than 35 clients within a day [18].

\section{Data collection tool}

A pre-tested and structured self - administered questionnaire was used to collect data. A questionnaire was adapted from different kinds of literature used in this study. Twenty Likert scale questions were used to measure job satisfaction.

\section{Data quality control}

Both data collectors and supervisors were given for oneday training. The training was given in lecture, discussion, and role-play ways. Completeness of data was checked in every day of activity and the necessary feedback was offered to data collectors in the next morning. Besides this, the principal investigator and an experienced data clerk entered and cleaned the data before the commencement of the analysis.

\section{Data processing and analysis}

The collected data was cleaned, coded and entered into Epi-data version 3.1 software and exported to SPSS version 20. Errors related to inconsistency were verified using cross tabulation and other data exploration methods. The results were presented in narrative, tables, and graphs. Furthermore, logistic regression, specifically bivariate and multivariate analysis was used to identify factors related to health professional job satisfaction. Those variables which were significant during bivariate analysis at $p$-value $\leq 0.2$ were taken to multivariable logistic regression analysis. The adjusted odds ratios together with their corresponding 95\% confidence intervals were computed. $P$-value $\leq 0.05$ with $95 \%$ confidence interval was considered to declare a variable as a statistically significant with the dependent variable.

\section{Results}

Socio-demographic characteristics of respondents

A total of 575 participants were involved in the study with a response rate of $87.5 \%$. The mean age of respondents was 27.13 years ( $S D= \pm 3.26$ years). Slightly more than half 316 (55\%) of the respondents were Male. The majority, $456(79.3 \%)$ and $548(95.3 \%)$ of them were in the age group less than 30 years and orthodox Christian in their religion respectively. A majority, 551(95.8\%) were Amhara ethnicity and 339(59\%) of the study participants were single in marital status. More than half (62.8\%) of the study participants were diploma holders and 301(52. $3 \%)$ of them were nurses (Table 1).

\section{Behavioral characteristics of respondents}

Among the total study participants, 32(5.6\%) of them were Khat chewers and of whom 24(75\%) and 8 (25\%) of them were chewing three times per week and daily respectively. Eight (1.4\%) of the respondents were cigarette smokers and all of them smokes half pack a day. Eighty (13.9\%) of the study participants practiced alcohol drinking out of which $72(90 \%)$ and $8(10 \%)$ of them were drinking two/ three and more times respectively a week.

\section{Institutional characteristics of respondents}

On average, three hundred eighty-five (67\%) of the study participants provided service for less than 35 clients per working day. The majority, 414(72\%) of the health professionals were working for less than or equal to $8 \mathrm{~h}$ per working day. Out of the total health care workers

Table 1 Socio-demographic characteristics of job satisfaction of health professionals working in governmental Health institutions Western Amhara Region, Ethiopia, $2016(n=575)$

\begin{tabular}{|c|c|c|c|}
\hline Variable & & Frequency & Percent \\
\hline \multirow[t]{2}{*}{ Sex } & Male & 316 & $55 \%$ \\
\hline & Female & 259 & $45 \%$ \\
\hline \multirow[t]{2}{*}{ Age } & $<30$ years & 456 & $79.3 \%$ \\
\hline & $\geq 30$ years & 119 & $20.7 \%$ \\
\hline \multirow[t]{3}{*}{ Religion } & Orthodox & 548 & $95.3 \%$ \\
\hline & Muslim & 16 & $2.8 \%$ \\
\hline & Protestant & 11 & $1.9 \%$ \\
\hline \multirow[t]{3}{*}{ Ethnicity } & Amhara & 551 & $95.8 \%$ \\
\hline & Oromo & 18 & $3.1 \%$ \\
\hline & Awi & 6 & $1 \%$ \\
\hline \multirow[t]{2}{*}{ Marital status } & Single & 339 & $59 \%$ \\
\hline & Married & 236 & $41 \%$ \\
\hline \multirow[t]{5}{*}{ Profession } & Physicians & 40 & $7 \%$ \\
\hline & Public Health officers & 119 & $20.7 \%$ \\
\hline & Nurses & 301 & $52.3 \%$ \\
\hline & Midwiferies & 76 & $13.2 \%$ \\
\hline & Others $^{a}$ & 39 & $6.8 \%$ \\
\hline \multirow[t]{2}{*}{ Educational status } & Diploma & 361 & $62.8 \%$ \\
\hline & Degree & 214 & $37.2 \%$ \\
\hline \multirow[t]{2}{*}{ Service year } & $<3$ years & 146 & $25.4 \%$ \\
\hline & $\geq 3$ years & 429 & $74.6 \%$ \\
\hline
\end{tabular}

ababoratory, Environmental Health, Pharmacy professionals 
involved in this study, 544(94.6\%) of them did not have health insurance. Four hundred twenty-three $(73.6 \%)$ of the study participants did not have reference manual.

\section{Level of job Jatisfaction}

The overall job satisfaction level of the health professional at governmental health facilities of western Amhara Region was $31.7 \%$ with 95\% CI $(27.7,35.3)$. Among the study participants, 72(12.5\%), 393(68.3\%), 71(12.3\%), $31(5.4 \%)$ and $8(1.4 \%)$ of them were strongly disagreed, disagreed, neutral, agreed and strongly agreed with the management style of their health institution respectively (Table 2).

\section{Factors associated with job satisfaction}

In the bivariate analyses sex, age, profession, educational status, service year, workload, alcohol drinking, the existence of health insurance and the presence of reference manuals met the variable selection criteria $(P$-value $<0.2)$ and were fitted to multivariable logistics regression analysis. After fitting multivariate logistic regression model variables including types of a health professional, Educational status, service year, workload, drinking alcohol and Availability of the reference guideline were identified as significant factors for the satisfaction of health professionals on their job. Variables that were negatively associated with bivariate logistic analysis became significantly associated factors on the multivariate logistic regression when the confounding variable was controlled. Those health workers who categorized as others (environmental health, laboratory, and pharmacy) were 4.68 (AOR $=4.68,95 \% \mathrm{CI}(1.04,20.9))$ times more likely to get satisfied than health officers, nurses and midwives. Those health professionals with the degree and above holders were 5.64 times more likely to get satisfied with their job compared to those with an educational status diploma $(\mathrm{AOR}=5.64,95 \% \mathrm{CI}(2.44,13))$. Health professionals who were serving in the institution for three and more years were 2.83 times more likely to get satisfied with their job compared to the counterpart $(\mathrm{AOR}=2.83,95 \% \mathrm{CI}(1.39$, 5.79)). Health professionals who were giving a service for 35 and more clients per day were 3.99 times more likely to get satisfied with their job compared to the counterpar$\mathrm{t}(\mathrm{AOR}=3.99, \quad 95 \%$ CI $(2.13,7.45))$. Those health professionals who were not drinking alcohol were 3.55 times more likely to get satisfied with their job compared to those who were drinking alcohol $(\mathrm{AOR}=3.55,95 \% \mathrm{CI}$ $(1.31,9.62))$ and those health professionals who had access to reference manual were 15.96 times more likely to get satisfied with their job compared to those with no access to the reference manual $(\mathrm{AOR}=15.96,95 \% \mathrm{CI}(8.49,30))$ (Table 3).

Table 2 Level of agreement about factors affecting job satisfaction among health professionals working in governmental health institutions in Western Amhara Region, Ethiopia, 2016

\begin{tabular}{|c|c|c|c|c|c|}
\hline \multirow[t]{2}{*}{ Satisfaction related to Job } & \multicolumn{5}{|c|}{ Degree of agreement } \\
\hline & \multirow{2}{*}{$\begin{array}{l}\text { Strongly disagree } \\
N(\%)\end{array}$} & \multirow{2}{*}{$\begin{array}{l}\text { Disagree } \\
N(\%)\end{array}$} & \multirow{2}{*}{$\begin{array}{l}\text { Neutral } \\
N(\%)\end{array}$} & \multirow{2}{*}{$\begin{array}{l}\text { Agree } \\
\text { N (\%) }\end{array}$} & \multirow{2}{*}{$\begin{array}{l}\text { Strongly Agree } \\
N(\%)\end{array}$} \\
\hline & & & & & \\
\hline Staff relationship & $40(7 \%)$ & $252(43.8 \%)$ & $31(5.4 \%)$ & $236(41 \%)$ & $16(2.8 \%)$ \\
\hline Working environment & $71(12.3 \%)$ & $376(65.4 \%)$ & $40(7 \%)$ & $80(13.9 \%)$ & $8(1.4 \%)$ \\
\hline Training opportunity & $80(13.9 \%)$ & $433(75.3 \%)$ & $16(2.8 \%)$ & $46(8 \%)$ & 0 \\
\hline Performance Evaluation & $64(11.1 \%)$ & $447(77.7 \%)$ & $16(2.8 \%)$ & $48(8.3 \%)$ & 0 \\
\hline Participate in decision making & $48(8.3 \%)$ & $449(78.1 \%)$ & $16(2.8 \%)$ & $54(9.4 \%)$ & $8(1.4 \%)$ \\
\hline Clear job description & $32(5.6 \%)$ & $447(77.7 \%)$ & $16(2.8 \%)$ & $64(11.1 \%)$ & $16(2.8 \%)$ \\
\hline Plan to leave the institution & $64(11.1 \%)$ & $383(66.6 \%)$ & $24(4.2 \%)$ & $96(16.7 \%)$ & $8(1.4 \%)$ \\
\hline Medical equipment supply & $31(5.4 \%)$ & $408(71 \%)$ & $48(8.3 \%)$ & $80(13.9 \%)$ & $8(1.4 \%)$ \\
\hline Incentives or allowance & $64(11.1 \%)$ & $455(79.1 \%)$ & $24(4.2 \%)$ & $32(5.6 \%)$ & 0 \\
\hline Enabling condition & $64(11.1 \%)$ & $463(80.5 \%)$ & $16(2.8 \%)$ & $32(5.6 \%)$ & 0 \\
\hline Frequency of supervision & $56(9.7 \%)$ & $456(79.3 \%)$ & $32(5.6 \%)$ & $31(5.4 \%)$ & 0 \\
\hline Availability of transportation & $56(9.7 \%)$ & $321(55.8 \%)$ & $32(5.6 \%)$ & $150(26.1 \%)$ & $16(2.8 \%)$ \\
\hline Government regulation & $48(8.3 \%)$ & $447(77.7 \%)$ & $16(2.8 \%)$ & 48(8.3\%) & $16(2.8 \%)$ \\
\hline Annual leave & $64(11.1 \%)$ & $415(72.2 \%)$ & $32(5.6 \%)$ & $64(11.1 \%)$ & 0 \\
\hline Promotional strategies & $64(11.1 \%)$ & $447(77.7 \%)$ & $16(2.8 \%)$ & $48(8.3 \%)$ & 0 \\
\hline Carrier development & $80(13.9 \%)$ & $415(72.2 \%)$ & $16(2.8 \%)$ & $64(11.1 \%)$ & 0 \\
\hline Annual increment of salary & $104(18.1 \%)$ & $407(70.8 \%)$ & $24(4.2 \%)$ & $40(7 \%)$ & 0 \\
\hline Location of the work & $56(9.7 \%)$ & 439(76.3\%) & 0 & 80 (13.9\%) & 0 \\
\hline
\end{tabular}


Table 3 Bivariate and multivariate analysis of factors affecting job satisfaction among health professionals working in governmental health institutions in Western Amhara Region, Ethiopia, 2016

\begin{tabular}{|c|c|c|c|c|c|c|}
\hline \multirow[t]{2}{*}{ Variables } & \multirow[t]{2}{*}{ Response } & \multicolumn{2}{|c|}{ Job satisfaction } & \multirow{3}{*}{$\begin{array}{l}\text { COR with 95\% } \\
\mathrm{Cl}\end{array}$} & \multirow{3}{*}{$\begin{array}{l}\text { AOR with } \\
95 \% \mathrm{Cl}\end{array}$} & \multirow{3}{*}{$\begin{array}{l}P \text { - } \\
\text { value }\end{array}$} \\
\hline & & Satisfied & Dissatisfied & & & \\
\hline & & $N(\%)$ & $N(\%)$ & & & \\
\hline \multirow[t]{2}{*}{ Sex } & Male & $86(27.1 \%)$ & $230(72.9 \%)$ & 1 & 1 & \\
\hline & Female & $96(37.1 \%)$ & 163 (62.9\%) & $1.57(1.10,2.24)$ & $1.09(0.62,1.92)$ & 0.747 \\
\hline \multirow[t]{2}{*}{ Age } & $<30$ years & $127(27.5 \%)$ & 329 (72.5\%) & 1 & 1 & \\
\hline & $\geq 30$ years & $55(46.2 \%)$ & $64(53.8 \%)$ & $2.22(1.47,3.37)$ & $0.57(0.29,1.14)$ & 0.115 \\
\hline \multirow[t]{5}{*}{ Profession } & Physicians & 32 (85.0\%) & $8(15.0 \%)$ & 1 & 1 & \\
\hline & $\mathrm{PHO}^{*}$ & 63 (52.9\%) & $56(47.1 \%)$ & $0.28(0.12,0.66)$ & $0.65(0.21,1.96)$ & 0.447 \\
\hline & Nurses & 47 (15.6\%) & 254 (84.4\%) & $0.05(0.02-0.10)$ & $0.27(0.07,1.01)$ & 0.052 \\
\hline & midwiferies & $16(21.1 \%)$ & 60 (78.9\%) & $0.07(0.03,0.17)$ & $1.01(0.24,4.24)$ & 0.983 \\
\hline & Others** & $24(61.5 \%)$ & 15 (38.5\%) & $0.4(0.15,1.09)$ & $4.68(1.04,20.9)$ & $0.043^{*}$ \\
\hline \multirow[t]{2}{*}{ Educational status } & Diploma & $71(19.7 \%)$ & 290 (80.3\%) & 1 & 1 & \\
\hline & Degree & $111(51.9 \%)$ & 103 (48.1\%) & $4.4(3.03,6.39)$ & $5.64(2.44,13)$ & $0.001^{*}$ \\
\hline \multirow[t]{2}{*}{ Service year } & $<3$ years & $24(16.4 \%)$ & $122(83.6 \%)$ & 1 & 1 & \\
\hline & $\geq 3$ years & $158(36.8 \%)$ & 271 (63.2\%) & $2.96(1.83,4.78)$ & $2.83(1.39,5.79)$ & $0.004^{*}$ \\
\hline \multirow[t]{2}{*}{ Work load } & Not loaded & 79 (20.5\%) & 306 (79.5\%) & 1 & 1 & \\
\hline & Loaded & $103(54.2 \%)$ & 87 (45.8\%) & $4.58(3.14,6.69)$ & $3.99(2.13,7.45)$ & $0.001^{*}$ \\
\hline \multirow[t]{2}{*}{ Drinking alcohol } & Yes & $16(20.0 \%)$ & $64(80.0 \%)$ & 1 & 1 & \\
\hline & No & $166(33.5 \%)$ & $329(66.5 \%)$ & $2.01(1.13,3.60)$ & $3.55(1.31,9.62)$ & $0.013^{*}$ \\
\hline \multirow[t]{2}{*}{ Existence of health insurance } & Yes & $16(51.6 \%)$ & $15(48.4 \%)$ & $2.42(1.17,5.02)$ & $2.61(0.72,9.40)$ & 0.142 \\
\hline & No & $166(30.5 \%)$ & $378(69.5 \%)$ & 1 & 1 & \\
\hline \multirow[t]{2}{*}{ Availability of the reference guideline } & Yes & $104(68.4 \%)$ & $48(31.6 \%)$ & $9.58(6.29,14.60)$ & $15.96(8.49,30)$ & $0.001^{*}$ \\
\hline & No & $78(18.4 \%)$ & $345(81.6 \%)$ & 1 & 1 & \\
\hline
\end{tabular}

${ }^{*} \mathrm{PHO}=$ Public Health Officer, others ${ }^{* *}=$ Environmental Health, Laboratory, Anesthetics, $\mathrm{n}=$ number, $\%=$ frequency

\section{Discussion}

This institution-based cross-sectional study sought to determine the job satisfaction level and its associated factors at Eastern Amhara region of Ethiopia. The study found out that job satisfaction of health professional working in Western Amhara Region was 31.7\%. This job satisfaction level is comparable with the two studies conducted in West Shewa Zone 34.9\% [13] and Dire Dawa City administrative, Ethiopia (34.5\%) [19].

In addition, this study revealed that the job satisfaction is lower than a study finding conducted in Ethiopia Jimma 58.6\% [12], Dessie town 53.8\% [14], federal police referral hospital, Addis Ababa, Ethiopia 43.2\% [20]. Similarly, the current study result was lower compared with studies done outside of the country Ethiopia. These are $52.1 \%$ at South Africa, $71 \%$ in Malawi, $82.6 \%$ in Tanzania [2] 67.1\% in Nigeria [1], 76\% in Nepal, [9] and $41 \%$ in Pakistan [11]. This discrepancy might be because the previous studies were mainly urban-based while the current covers large geographic area in which majority was rural.
On the other hand, the current finding was higher than the finding revealed at $20.4 \%$ at South Rand Hospital of South Africa [21] and Serbia (22.4\%) [10]. The discrepancies might be related to differences in the presence of reference manual and health insurance, monthly salary, education opportunity, and workload imbalance. Besides these, most health facilities selected in this study were remote and had poor infrastructure than the previous study. These might also cause the variation of the results.

Concerning about factors associated with job satisfaction, this study identified that the presence of guideline that helps professionals in referring, alcohol drinking status, workload, service year, educational status and types of professions are significantly associated with job satisfaction level of healthcare professionals.

Pharmacists, Environmental Health and Laboratory professionals were 4.68 times more likely to get satisfied with their job compared to Public health officers, Nurses, and Midwives. This finding is in line with the study conducted in Jimma [12]. 
Moreover, educationally health professionals with degree holder were 5.64 times more likely got satisfaction with their job compared with the diploma. This result is consistent with the finding from Vietnam [15]. Health professionals who were serving in the institution for $\geq 3$ years were 2.83 times more likely got satisfaction with their job compared to $<3$ years' service. This result is in agreement with the finding from Vientiane capital and Bolikhamsai province, Lao PDR [16].

In addition to this, health professionals who were giving a service $\geq 35$ clients per day were 3.99 times more likely to get satisfaction with their job compared to those with giving a service for $<35$ clients per day. The possible reason for the finding might be related to the satisfaction they got from the service they provided for the patients who suffer from diseases.

Those health professionals who were not drinking alcohol were 3.55 times more likely to get satisfaction with their job compared to those who were drinking alcohol. The possible justification for the finding might be related to those who used to drink alcohol might get bored with their job not because of the job itself but rather because of the problem related to alcohol drinking.

Those health professionals who had access to the reference manual were 15.96 times more likely to get satisfied with their job compared to those with no access to reference manual. This might happen because professionals who had access to reference manual may perform their job as per the guideline and might get satisfaction with their job because clients who got the service as per the guideline may appreciate them and professionals might be motivated by the appreciation provided by the clients.

Concerning the gender of the respondents, even though it was not identified as a predictor variable in the multivariate analysis, female health professionals' were more $(37.1 \%)$ satisfied than their male colleagues (27.1\%). This might be true that drinking alcohol was observed more frequently among male than female health professionals, and alcohol drinking was identified as significant factors with employee job satisfaction. A similar study conducted at Dire Dawa city administrative, Ethiopia suggested the similar satisfaction levels of male and female health professionals (33.8\% for male and $33.6 \%$ for female, respectively) [19]. This finding was also similar to a study finding conducted at North Vietnam, which revealed that, females are more satisfied than the counterpart [22]. This might be because females have fewer problems with the behavioral characteristics. In contrary, a study conducted at Police Referral Hospital in Addis Ababa revealed $23.3 \%$ and the satisfaction levels observed between male (51.1\%) and female (48.9\%) [20] were the same.

\section{Conclusion}

In conclusion, this study revealed that only one-third of the health professionals working in Eastern Amhara Region were satisfied on their job. The presence of health professionals' guides to accomplish their activities, alcohol drinking, workload, experience, educational status and types of professions were identified as important predictors of job satisfaction. Furthermore, the presence of guideline that helps healthcare professionals, drinking alcohol, workload, service year, educational level and types of the profession were identified as factors that affect job satisfaction level of the study population. The concerned bodies should develop strategies on the identified factors to enhance the job satisfaction level of health care professional at western Amhara region, Ethiopia. Arranging opportunities for educational development is also one important strategy to enhance the workers satisfaction level.

\section{Abbreviation}

AOR: Adjusted Odd Ratio; DMU: Debre Markos University; JS: Job satisfaction; JU: Jimma University

\section{Acknowledgements}

We would like to express our gratitude to data collectors and supervisors for their timely submission of completed questionnaires and to respondents for their willingness to participate in this study. We want also like to thank Debre Markos University (DMU) for arranging internet and library services. Last but not least, we would like to forward our gratitude for Belachew Zerihun Dememe (PhD), who a fluent in English and assistant profession of TOFL, for his contribution in revising, editing the manuscript for its grammar, wording and language.

\section{Availability of data and materials \\ "The dataset will not be shared in order to protect the participants" identities".}

\section{Authors' contributions}

$\mathrm{KT}$ conceived and designed the study, performed analysis and interpretation of data. MW and CT supervised the design conception, analysis, interpretation of data and made critical comments at each step of the research. CT drafted the manuscript. All authors read and approved the final Manuscript.

\section{Ethics approval and consent to participate}

The Study was reviewed and approved by the Ethical review committee of Debre Markos University, College of Medicine and Health Science. All participants were informed of the aim of the study and their full right to withdraw or refuse to participate before their verbal consent was obtained.

\section{Competing interests}

The authors declared that no conflict of interest.

\section{Publisher's Note}

Springer Nature remains neutral with regard to jurisdictional claims in published maps and institutional affiliations.

\section{Author details}

${ }^{1}$ Emergency Department Case Team, Kuy Health Center, Kuy District, East Gojjam Zone, Amhara Region, Ethiopia. ²Department of Public Health, College of Health Science, Debre Markos University, P.O. Box: 269, Debre Markos, Ethiopia. 
Received: 4 December 2017 Accepted: 13 April 2018

Published online: 17 April 2018

\section{References}

1. George J, Jones G. Understanding and managing organizational behavior. 5th ed. Upper Saddle River: Pearson Prentice Hall; 2008.

2. Robbins SP, Judge TA. Organizational behavior. 12th ed. Upper Saddle River: Pearson Prentice Hall; 2007.

3. Al-Aameri AS. Job satisfaction and organizational commitment for nurses. Saudi Medical Journal. 2000;21(6):231-5.

4. Gibson LL, Donnelly JH, Ivancevich JM. Fundamentals of management. Chicago: Irwin; 2000.

5. Al-Hussami M. A study of nurses' job satisfaction:the relationship to organizational commitment, perceived organizational support, transactional leadership, transformational leadership and level of education. Eur J Sci Res. 2008;22(2):286-95

6. Mowday R. Strategies for adapting to high rate of employee turnover. Human resource management. Int J Nurs Stud. 2006;39:867-8.

7. Government of Ethiopia and the World Bank. Health sector review, Ethiopian job satisfaction and its determinants social sector studies. In: Sanitation AAC, editor. Mega. 1st ed; 2004.

8. Pillay R. Work satisfaction of professional nurses in South Africa: a comparative analysis of the public and private sectors. BMC Human Resources for Health. 2009;7(15):15.

9. Chaulagain N, Khadka DK. Factors influencing job satisfaction among healthcare professionals at Tilganga eye Centre, Kathmandu, Nepal. International journal of scientific \& technology research. 2012;1(11):32-6.

10. Jovic-Vranes A, Vesna B, Boris V, Natasa M. Job satisfaction in Serbian health care workers who work with disabled patients. Cent Eur J Med. 2008;3(2):221-4.

11. Kumar, et al. Job satisfaction among public health professionals working in public sector: a cross sectional study from Pakistan. Hum Resour Health. 2013;11(2):2.

12. Yami A, et al. Job satisfaction and its determinants among health workers in Jimma University specialized hospital, Southwest Ethiopia. Ethiop J Health Sci. 2011;21:19-27.

13. Mengistu MM, Bali AG. Factors associated to job satisfaction among healthcare Workers at Public Hospitals of west Shoa zone, Oromia regional state, Ethiopia. Science Journal of Public Health. 2015;3(2):161-7.

14. Mulu A, Ayenew W, Kerrie Y. Job satisfaction and its determinants among pharmacy professionals working in Dessie town, Northeast Ethiopia.. Wollo university, Dessie, Ethiopia. International Journal of Chemical and Natural Science. 2015;3(2):253-7.

15. Tran BX, et al. Factors associated with job satisfaction among commune health workers: implications for human resource policies. Glob Health Action. 2013;6(1):18619.

16. Senbounsou Khamlub MD, Harun-or-Rashid MABS, Hirosawa T, Outavong P, Sakamoto J. Job satisfaction of health-care workers at health centers in Vientiane capital and Bolikhamsai province, Lao PDR. Nagoya J Med Sci. 2013;75:233-41.

17. East Gojjam Zonal Health Department: Second quarter major activities report. 2015.

18. Ethiopian Ministry of Health: The Ethiopian reform implementation guideline. 2012

19. Abreham Melaku Gobena: Factors affecting job satisfaction among health professionals in Dire Dawa administration. 2017.

20. Tadese T, Mohamed A, Mengistie A. Assessment of factors influencing job satisfaction among health care providers, federal police referral hospital, Addis Ababa, Ethiopia. Ethiop J Health Dev. 2015;29(2):119-26.

21. Jackie Mamitsa Banyana Ramasodi: Factors influencing job satisfaction among healthcare professionals at south Rand Hospital, South Africa. 2010

22. Van Nguyen $H$, Duong HT, Vu TT. Factors associated with job satisfaction among district hospital health workers in northern Vietnam: a crosssectional study. Int J Health Plann Manag. 2017;32:163-79.

\section{Ready to submit your research? Choose BMC and benefit from:}

- fast, convenient online submission

- thorough peer review by experienced researchers in your field

- rapid publication on acceptance

- support for research data, including large and complex data types

- gold Open Access which fosters wider collaboration and increased citations

- maximum visibility for your research: over $100 \mathrm{M}$ website views per year

At BMC, research is always in progress.

Learn more biomedcentral.com/submissions 